\title{
Isolasi, identifikasi, dan penyiapan sediaan kering Bakteri Asam Laktat yang berpotensi sebagai probiotik dari dadih asal Sijunjung Sumatera Barat
}

\section{Isolation, identification, and preparation of dried Lactic Acid Bacteria derived from dadih Sijunjung West Sumatra as a potential probiotics}

Yulia Helmi Diza*1, Alfi Asben ${ }^{2}$, dan Tuty Anggraini ${ }^{2}$

1 Balai Riset dan Standardisasi Industri Padang

Jl. Raya LIK No.23 Ulu Gadut, Padang, Indonesia

2 Fakultas Teknologi Pertanian, Universitas Andalas

Kampus Limau Manis, Padang, Indonesia

* e-mail: yuliahelmi1@gmail.com

\begin{tabular}{l}
\hline INFO ARTIKEL \\
\hline Sejarah artikel: \\
Diterima: \\
5 Oktober 2020 \\
Direvisi: \\
19 Desember 2020 \\
Diterbitkan: \\
28 Desember 2020 \\
\hline
\end{tabular}

\section{Kata kunci:}

dadih;

bakteri asam laktat

(BAL);

isolasi;

identifikasi

\section{Keywords:}

\section{dadih;}

lactic acid bacteria

(LAB);

isolation;

identification

\begin{abstract}
ABSTRAK
Dadih merupakan produk fermentasi susu kerbau yang berasal dari Sumatera Barat, kaya akan bakteri asam laktat yang berpotensi sebagai probiotik. Berdasarkan hal tersebut, telah dilakukan penelitian untuk mengisolasi, mengidentifikasi, menguji karakteristik probiotik dan menyiapkan sediaan kering bakteri asam laktat dari dadih Sijunjung Sumatera Barat. Isolasi bakteri dadih dilakukan sampai diperoleh koloni yang seragam dilanjutkan dengan identifikasi bakteri menggunakan Kit API 50 CHL Kemudian dilakukan pengujian sifat probiotiknya, dan dilanjutkan dengan proses penyediaan bakteri kering menggunakan bahan pengkapsul natrium alginat dan skim secara freeze drying. Terhadap sediaan bakteri kering dihitung rata-rata kadar air dan viabilitasnya. Hasil penelitian menunjukkan bahwa isolat bakteri dari dadih merupakan bakteri gram positif, berbentuk sel batang, ujung bentuk persegi dan posisi berantai. Hasil identifikasi menggunakan Kit API 50 CHL, teridentifikasi sebagai Lactobacillus paracasei ssp paracasei yang potensial sebagai probiotik dengan viabilitas yang baik, yaitu $89,52 \%$.
\end{abstract}

ABSTRACT

Dadih is a fermented product of buffalo milk originating from West Sumatra, rich in lactic acid bacteria that recognized as potential probiotic. Therefore, the aim of this study was to isolate, identify and characterize the dried lactic acid bacteria that derived from dadih Sijunjung West Sumatra. The isolated single colony of bacterial form dadih was identified and charaterized using the API 50 CHL Kit. The bacterial was then encapsulated using sodium alginate and skim with freeze drying method. Moisture content and viability of dried lactic acid bacteria were evaluated. As the results, the isolated bacterial from dadih were identified as Lactobacillus paracasei ssp paracasei with the characteristics as a gram-positive bacteria with a rod and square shaped in chain position. Moreover, the viability of dried dried lactic acid was $89.52 \%$. which is classify as a good viability of probiotic's property.

(C) 2020 Penulis. Dipublikasikan oleh Baristand Industri Padang. Akses terbuka dibawah lisensi CC BY-NC-SA

\section{Pendahuluan}

Dadih merupakan pangan tradisional dari Sumatera Barat mirip dengan dahi dari India, yang berasal dari olahan susu kerbau, difermentasi secara alami dan spontan dalam wadah bambu pada suhu ruang selama 24 sampai 48 jam (Kusumo, 2010; Rizqiati et al., 2009; Surono et al., 2008; Wirawati et al., 2017). Dadih ini menjadi salah satu produk olahan susu yang sangat populer di Sumatera Barat seperti di daerah Bukittinggi,
Padang Panjang, Solok, Lima Puluh Kota dan Tanah Datar, selalu ditemui terutama dalam acara-acara adat seperti acara pernikahan atau pengangkatan gelar datuak (Surono, 2016).

Berdasarkan data Sumatera Barat dalam Angka tahun 2018 (BPS, 2018), pada tahun 2017 populasi kerbau di Kabupaten Sijunjung sebanyak 14.813 ekor, terbanyak kedua setelah kabupaten Agam (19.764 ekor). Besarnya populasi kerbau ini memungkinkan Kabupten Sijunjung menjadi salah satu daerah yang berpotensi cukup besar 
dalam memproduksi dadih. Produksi susu kerbau dari Kabupaten Agam, Padang Pariaman, dan Sijunjung pada tahun 2014 sebesar 530.098 Liter dan total produksi susu kerbau Sumatera Barat sebanyak 1.188.438 Liter.

Teknologi pembuatan dadih sangat sederhana. Sebanyak $\pm 150 \mathrm{ml}$ susu kerbau yang baru diperah langsung dimasukkan ke dalam sepotong ruas bambu segar dan ditutup dengan daun pisang. Selanjutnya didiamkan atau difermentasi secara alami mengandalkan mikroba dari bambu yang digunakan, dari daun pisang sebagai penutup bambu dan dari susu itu sendiri dalam suhu ruang hingga terbentuknya gumpalan. Dalam waktu 24 jam susu akan menggumpal menjadi semacam puding atau tahu putih kekuning-kuningan, kental dan beraroma khas (kombinasi aroma susu dan bambu). Setelah proses fermentasi selesai, dadih dapat langsung dimakan (Kusumo, 2010; Wirawati et al., 2017).

Berdasarkan dari beberapa sumber penelitian telah diketahui bahwa dadih banyak mengandung BAL, yang sangat potensial sebagai probiotik (Adrianto, 2011; Elida, 2002; Hardiningsih et al., 2006; Kusumo, 2010; Pratama et al., 2019; Rizqiati et al., 2009; Sunaryanto and Marwoto, 2013; Surono, 2016). BAL yang termasuk dalam probiotik diantaranya Staphylococcus raffinolactis ct 4, Lactococcus piscum dl 4, Leuconostoc paramesenteroides bl2, Leuconostoc mesenteroides al2, Lactobacillus brevis ae4, Lactobacillus casei, Lactobacillus plantarum, dan Lb. Plantarum dan Lactobacillus fermentum. Kandungan nutrisi yang tinggi dalam dadih susu kerbau, menjadikannya medium yang baik untuk pertumbuhan bakteri asam laktat. Dengan demikian menjadi hal yang menarik untuk dibahas lebih lanjut mengenai potensi bakteri asam laktat yang yang terkandung dalam dadih susu kerbau untuk dijadikan kandidat probiotik.

Probiotik merupakan sejumlah bakteri yang memberikan efek yang menguntungkan kesehatan hostnya apabila dikonsumsi dalam jumlah yang cukup (WHO and FAO, 2006). Bakteri probiotik dapat memperbaiki keseimbangan mikroflora intestinal pada saat masuk dalam saluran pencernaan kesehatan bagi manusia dan binatang, termasuk menurunkan symptom pada lactose intolerant dan meningkatkan nilai gizi bahan pangan. Probiotik juga menunjukkan sifat antimutagen, anti karsinogen dan hypokolesterol, anti antagonis terhadap bakteri pathogen dalam lambung, menurunkan kecenderungan alergi dan efek immunomodulatory, mencegah diare dan meningkatkan sistem kekebalan tubuh, juga dapat menghambat pertumbuhan bakteri berbahaya, menurunkan hipertensi, mencegah sembelit, menurunkan senyawa karsinogen, membantu mencerna laktosa, membantu penyerapan mineral, membantu pembentukan vitamin, mencegah dan membantu penyembuhan penyakit atopic (Zubaidah et al., 2012).

Saat ini banyak dikembangkan produk pangan probiotik. Pangan probiotik merupakan produk hasil fermentasi susu atau bahan baku lainnya dengan menggunakan bakteri probiotik, diantaranya BAL. BAL termasuk golongan bakteri mikroaerofilik, gram positif yang memfermentasi heksosa menghasilkan asam laktat. Beberapa aspek seperti keamanan, fungsional, dan karakterisasi teknologi menjadi pertimbangan utama dalam proses seleksi mikroba probiotik. Aspek keamanan termasuk spesifikasi seperti : kemurniannya (menyehatkan saluran pencernaan), bersifat non patogenik, dan tahan terhadap antibiotik. Aspek fungsional seperti kemampuan hidup dan tahan dalam saluran pencernaan, imunomodulation, bersifat antagonis, dan tidak mengalami mutasi. Strain probiotik juga harus tahan dan tetap hidup selama proses pengolahan makanan dan penyimpanan, mudah diaplikasikan pada produk makanan, dan tahan terhadap proses psikokimia pada makanan (Prado et al., 2008).

Enkapsulasi didefenisikan sebagai proses memerangkap suatu substansi (bahan aktif) dengan bahan lain (sebagai material dinding) (Nedovic et al., 2011), atau suatu inti yang berupa komponen bioaktif atau fungsional yang dibungkus dengan suatu bahan kedua membentuk mikrokapsul (Smith and Charter, 2010). Bahan yang dipakai untuk enkapsulasi biasa disebut engkapsulan, coating, membran, kulit, kapsul, bahan pembawa, fase eksternal atau matriks, yang akan mengisolasi bahan aktif dari lingkungan sekitarnya sampai bahan aktif itu dilepas ke lingkungannya (Nedovic et al., 2011; Smith and Charter, 2010). Teknologi enkapsulasi telah digunakan oleh industri pangan dalam beberapa tahun. Komponen pangan yang dapat dienkapsulasi antara lain flavor, pewarna, penstabil, antioksidan, enzyme, probiotik, lemak, garam mineral dan vitamin.

Mikroenkapsulasi adalah mempertahankan sel-sel dalam matrik enkapsulan atau membran sebagai alternatif untuk melindungi probiotik, dengan menyediakan kondisi mikro lingkungan yang nyaman, meningkatkan daya hidup dan memungkinkan dalam kontrol pelepasan sel dalam saluran usus. Teknologi ini terbukti menjadi salah satu cara paling efektif dalam melindungi probiotik selama proses pengolahan dan penyimpanan. Keuntungan proses enkapsulasi adalah melindungi probiotik terhadap kondisi stress atau tekanan dari lingkungan (Ozyurt and Otles, 2014)

Material enkapsulasi haruslah termasuk dalam komponen Generally Recognized as Safe (GRAS), dapat digunakan dalam makanan, seperti xanthan gum, turunan pati, cellulose acetat phthalate, kasein, protein whey, chitosan, carboximethyl cellulose, carrageenan, gelatin, pectin, vegetable gum, lemak dan alginate (Ozyurt and Otles, 2014) .

Beberapa penelitian engkapsulasi bakteri yang telah dilakukan menggunakan matriks alginat diantaranya adalah enkapsulasi L. bulgaricus dalam alginat-milk. Proses enkapsulasinya dapat mempertahankan bakteri pada $\mathrm{pH}$ rendah $(\mathrm{pH} 2,0$ dan 2,5), konsentrasi garam empedu 1 dan $2 \%$ serta tahan disimpan selama 1 bulan (Shi et al., 2013). L. plantarum TN8 dalam 2\% natrium alginat, menghasilkan sel yang memiliki ketahanan yang signifikan lebih tinggi terhadap cairan lambung dan saluran pencernaan dibanding yang tidak dienkapsulasi (Trabelsi et al., 2013). B. adolescentis 15703T yang dienkapsulasi dengan alginat-gelatin menghasilkan sel yang lebih tahan terhadap simulasi cairan lambung $(\mathrm{pH}$ 2, selama 2 jam) (Annan et al., 2008). L. acidophilus ATCC 43121 yang dienkapsulasi dengan natrium alginat menghasilkan sel yang lebih tahan terhadap paparan cairan lambung buatan dan perlakuan panas daripada 
yang tidak dienkapsulasi (Kim et al., 2008). L. gasseri (L) yang dienkapsulasi dengan citosan dan B. bifidum yang dienkapsulasi dengan calcium alginat meningkatkan ketahanan terhadap kondisi lambung buatan ( $\mathrm{pH}$ 2,0 selama 2 jam) dan larutan garam empedu (3\%), selama 2 jam) ketika digunakan (Chávarri et al., 2010). L. casei ATCC 393 yang dienkapsulasi dengan alginat, chitosan dan karboksimetil citosan dengan metode ekstrusi sukses melindungi bakteri terhadap kondisi negatif lingkungan (Li et al., 2011).

Alginat termasuk dalam hidrokoloid alami, merupakan biopolymer larut air yang diekstrak dari rumput laut coklat seperti Sargassum sp. dan Turbinaria sp. (Husni et al., 2012) yang merupakan kopolimer rantai lurus dari residu asam $\beta$-(1-4)-D-manuronat (M) dan asam $\alpha$-(1-4)-L-guluronat (G) yang membentuk homopolimer $\mathrm{M}$ atau $\mathrm{G}$ dan blok heteropolimer $\mathrm{MG}$ (Cardenas et al., 2003). Alginat telah digunakan secara luas untuk enkapsulasi probiotik skala laboratorium (Rokka and Rantamäki, 2010). Garam alginat larut dalam air, tetapi mengendap dan membentuk jel pada $\mathrm{pH}$ lebih rendah dari tiga. Alginat dapat membentuk jel (formasi egg-box), film, manik (beads), pelet, mikropartikel, dan nano partikel (Sarmento et al., 2007).

Natrium alginat merupakan garam natrium dari asam alginat yang larut dalam air, membentuk koloid kental dan tidak larut dalam medium dengan $\mathrm{pH}$ kurang dari 3, etanol, dan pelarut organic lainnya. Larutan natrium alginat stabil pada $\mathrm{pH}$ 4-10. Viskositasnya dapat bervariasi, tergantung pada konsentrasi, $\mathrm{pH}$, temperature, atau adanya ion logam. Viskositas larutan akan menurun pada $\mathrm{pH}$ di atas 10.

Alginat, dalam penggunaannya sebagai bahan enkapsulasi biasanya dikombinasikan dengan bahan lainnya, seperti dengan penambahan prebiotik (HiMaize) (Homayouni et al., 2008; Sultana et al., 2000), terigu dan polard (Widodo et al., 2003) sebagai bahan pengisi (filler), chitosan sebagai coating (Krasaekoopt et al., 2003), dan pektin untuk membentuk kompleks alginat-pektin yang lebih kuat (Sandoval-castilla et al., 2010).

Selain bahan berbasis polisakarida, bahan berbasis protein juga sering digunakan pada proses enkapsulasi bakteri probiotik (Rokka and Rantamäki, 2010). Bahan berbasis protein seperti gelatin, skim, whey, dan caseinate digunakan sebagai bahan pembawa (carriers) pada enkapsulasi probiotik menggunakan teknik spray drying (Lian et al., 2003; Picot and Lacroix, 2004; Triana et al., 2006). Penggunaan bahan berbasis protein sebagai bahan enkapsulasi pada teknik spray drying dikarenakan sifatnya yang memiliki kemampuan mengemulsi serta mampu melindungi sel bakteri dari panas (thermoprotectan). Bakteri yang dienkapsulasi dengan teknik spray drying akan release sempurna di dalam produk susu fermentasi (Krasaekoopt et al., 2003).

Susu skim adalah bagian susu yang tertinggal setelah krim diambil sebagian atau seluruhnya. Susu skim mengandung semua komponen gizi dari susu kecuali lemak dan vitamin yang larut dalam lemak. Seringkali disebut sebagai susu bubuk tak berlemak yang banyak mengandung protein dengan kadar air sebesar 5\% (Handayani et al., 2014). Karena lemaknya telah dipisahkan, susu skim hanya mengandung $0,5-2,0 \%$.
Pada penelitian ini dilakukan pengembangan produk sediaan kering BAL dari dadih yang berasal dari susu kerbau daerah Sijunjung Sumatera Barat. BAL di isolasi, diidentifikasi dan dienkapsulasi untuk dapat diaplikasikan sebagai suatu produk probiotik yang bisa dikonsumsi. Diharapkan hasil dari penelitian ini dapat memperkaya dasar-dasar pengembangan produk probiotik yang berguna bagi masyarakat kedepannya.

\section{Metode}

Pada penelitian ini, dilakukan isolasi bakteri dadih yang berasal dari Kabupaten Sijunjung dan identifikasi bakteri menggunakan Kit API 50 CHL di Laboratorium Mikrobiologi Balai Veteriner Bukittinggi, dilanjutkan pengujian sifat probiotiknya, dan dilakukan proses penyiapan sediaan bakteri kering menggunakan bahan pengkapsul natrium alginat dan skim secara freeze drying. Terhadap sediaan bakteri kering dihitung ratarata kadar air dan viabilitasnya. Penelitian ini merupakan penelitian melalui eksperimen di laboratorium. Data dikumpulkan dengan cara pengamatan langsung setelah objek penelitian diberikan perlakuan, kemudian melakukan serangkaian pengujian. Metode Isolasi dan Identifikasi sebagaimana ditampilkan pada Gambar 1.

\subsection{Proses isolasi bakteri asam laktat (BAL) dari dadih}

Isolasi dilakukan dengan mensuspensikan $1 \mathrm{~g}$ dadih umur 48 jam, ke dalam $9 \mathrm{ml}$ larutan $0,85 \% \mathrm{NaCl}$ (pengenceran $10^{-1}$ ). Kemudian dibuat pengenceran berseri sampai $10^{-6}$ ke dalam larutan garam fisiologis. Ditambahkan 15 - $20 \mathrm{ml}$ media MRSA ke dalam cawan petri steril untuk pertumbuhan bakteri asam laktat, tunggu sampai agar membeku, 3 seri pengenceran terakhir dipleting sebanyak $0,1 \mathrm{ml}$ kedalam cawan. Dilakukan penggoyangan secara mendatar, inkubasi pada suhu $30^{\circ} \mathrm{C}$ selama $48-72$ jam.

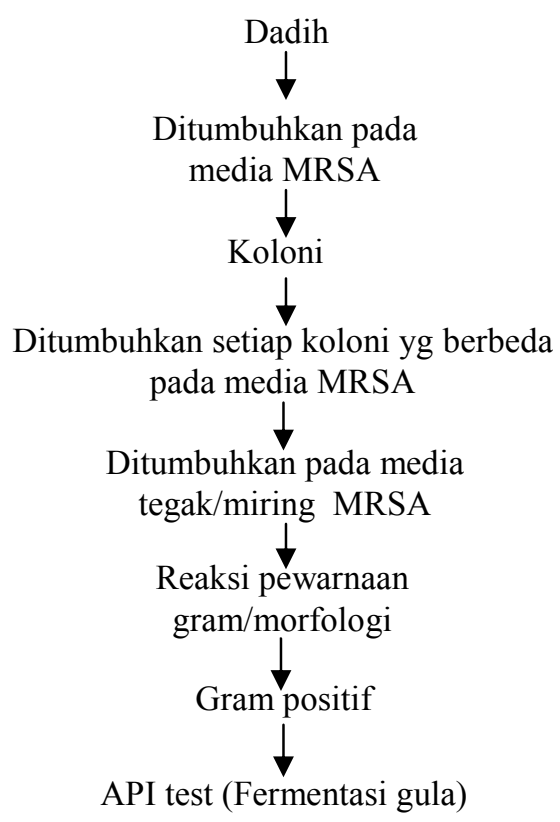

Gambar 1. Metoda isolasi dan identifikasi bakteri asam laktat pada dadih (Safitri, 2010) (dengan modifikasi). 
Koloni yang diamati dengan penampakan rata dan berwarna kuning atau abu-abu sampai coklat disekitar koloni. Koloni dengan warna dan ukuran yang berbeda digoreskan kembali ke medium yang sama dengan di atas. Penggoresan dilakukan sampai didapat koloni yang seragam, koloni yang sudah murni dipilih dan dilakukan pewarnaan gram.

Isolat terpilih dari pengamatan gram positif, dilakukan pengelompokan berdasarkan bentuk sel (batang, bulat, oval), untuk mengidentifikasi genus bakteri asam laktat. Selanjutnya isolat ditumbuhkan ke agar miring selama dua hari sebagai kultur stok. Kultur stok kemudian diawetkan pada suhu $5^{\circ} \mathrm{C}$, dan harus diperbaharui setiap 2 bulan. Bila akan digunakan pada setiap tahap pengujian bakteri asam laktat, kultur stok dipersiapkan menjadi kultur kerja.

\subsection{Identifikasi bakteri asam laktat}

Isolat dengan karakter gram positif, berbentuk bulat atau batang, dikarakterisasi lebih lanjut kemampuannya dalam memfermentasi 49 jenis karbohidrat untuk diidentifikasi jenisnya menggunakan kit API $50 \mathrm{CHL}$ (Biomerieux, Perancis). Isolat umur 24 jam digoreskan pada media MRSA sehingga didapatkan koloni murni dalam jumlah banyak, selanjutnya disuspensikan pada medium API CHL dan dihomogenisasi. Suspensi isolat pada medium API CHL diteteskan pada API CHL strips yang berisi substrat 49 macam karbohidrat kemudian diinkubasikan pada suhu $37{ }^{\circ} \mathrm{C}$ selama 48 jam. Kemampuan isolat dalam memfermentasi substrat diamati pada 24 dan 48 jam inkubasi. Perubahan warna dari biru gelap menjadi kuning dinyatakan sebagai perubahan yang positif. Hasil yang diperoleh diolah dengan menggunakan software Apiweb sehingga didapatkan data jenis bakteri untuk masing-masing isolat.

\subsection{Pengujian sifat probiotik (Ketahanan terhadap pH lambung (Elida, 2002)}

Ketahanan tiap kultur terhadap $\mathrm{pH}$ lambung dilakukan untuk mengetahui kemampuannya bertahan dalam lambung dan saluran pencernaan yang mempunyai $\mathrm{pH}$ yang asam. Sebanyak $0,1 \mathrm{ml}$ suspensi bakteri dari medium MRSB (24 jam) dimasukkan ke dalam satu seri tabung yang berisi $2 \mathrm{ml}$ larutan PBS steril yang mempunyai $\mathrm{pH} 3,5$ (pengaturan $\mathrm{pH}$ dilakukan dengan penambahan asam klorida $(\mathrm{HCl})$. Rata-rata jumlah bakteri yang tumbuh dihitung setelah inkubasi 0 ; 4; 7; dan 24 jam pada suhu $37^{\circ} \mathrm{C}$ dengan plating sebanyak 100 ul pada MRSA.

\subsection{Enkapsulasi bakteri probiotik dan proses sediaan kering}

Suspensi biopolimer yang digunakan yaitu $\mathrm{Na}$ alginat : skim, dibuat dengan konsentrasi 5\% dalam perbandingan yang sama (1:1). Sebelum digunakan, suspensi biopolymer disterilisasi dengan autoklaf (Asben et al., 2014). Suspensi biopolymer steril yang telah didinginkan kemudian ditambahkan suspensi sel hasil isolasi (kultur berumur 16 jam pada media MRSB) sebanyak 10\% atau dengan perbandingan 9:1 (Sandovalcastilla et al., 2010) dengan modifikasi, lalu dikocok hingga homogen dan selanjutnya dilakukan pengeringan dengan metode freeze drying, yang telah diatur kondisi operasinya. Pengamatan dan perhitungan dilakukan terhadap rata-rata jumlah bakteri awal, jumlah bakteri setelah dienkapsulasi dan dikeringkan (viabilitas bakteri) serta kadar air sediaan bakteri kering.

\section{Hasil dan pembahasan}

\subsection{Isolasi bakteri asam laktat dari dadih}

Dadih yang digunakan dalam penelitian ini adalah dadih yang berasal dari daerah Sijunjung (Gambar 2). Kabupaten Sijunjung termasuk dalam 3 (tiga) kabupaten/kota dengan populasi kerbau terbesar di Sumatera Barat.

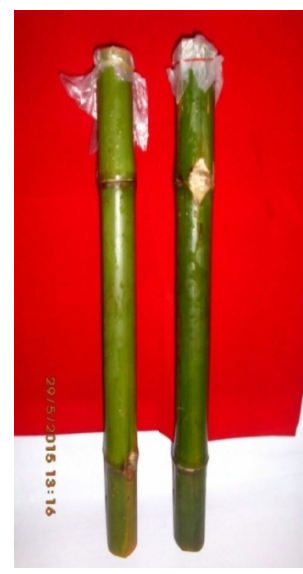

(a)

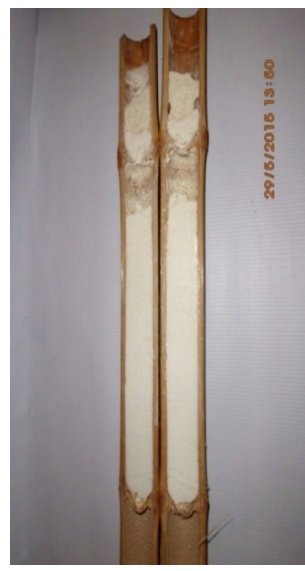

(b)
Gambar 2. (a) Bambu sebagai wadah fermentasi susu kerbau, (b) Dadih Sijunjung umur 2 hari (48 jam)

Bakteri dari dadih selanjutnya ditumbuhkan pada media MRSA. Koloni yang tumbuh diamati dari segi bentuk dan warna. Setiap koloni yang memberikan penampakan yang berbeda ditumbuhkan kembali ke media MRSA. Kemudian koloni dipindahkan ke media agar miring. Selanjutnya dilakukan pengujian pewarnaan gram. Isolat yang dipilih adalah isolat dengan karakter gram positif, berbentuk bulat atau batang. Isolat terpilih ini dikarakterisasi lebih lanjut kemampuannya dalam memfermentasi 49 jenis karbohidrat untuk diidentifikasi jenisnya menggunakan kit API 50 CHL (Biomerieux, Perancis).

Dari bakteri yang tumbuh pada media MRSA, diambil 6 koloni yang berbeda, yang ditumbuhkan kembali ke media MRSA untuk dilanjutkan dengan pengujian pewarnaan gram. Hasil pewarnaan gramnya dapat dilihat pada Tabel 1. 
Tabel 1.

Hasil pewarnaan gram beberapa isolat dadih Sijunjung

\begin{tabular}{|c|c|c|c|}
\hline No & $\begin{array}{l}\text { Kode } \\
\text { isolat }\end{array}$ & Pengamatan & Hasil pewarnaan gram \\
\hline 1. & $\mathrm{~A}$ & $\begin{array}{l}\text { - Koloni } \\
\text { cembung } \\
\text { tunggal } \\
\text { berwarna putih } \\
\text { - Pewarnaan } \\
\text { gram: positif } \\
\text { - Bentuk:batang }\end{array}$ & \\
\hline 2. & B & $\begin{array}{l}\text {-Koloni kecil- } \\
\text { kecil berwarna } \\
\text { putih } \\
\text { kekuningan } \\
\text {-Perwarnaan } \\
\text { gram:positif } \\
\text {-Bentuk:batang }\end{array}$ & \\
\hline 3. & $\mathrm{C}$ & $\begin{array}{l}\text {-Koloni } \\
\text { cembung } \\
\text { tunggal } \\
\text { berwarna putih } \\
\text {-Pewarnaan } \\
\text { gram:positif } \\
\text {-Bentuk:batang }\end{array}$ & \\
\hline 4. & $\mathrm{D}$ & $\begin{array}{l}\text {-Koloni } \\
\text { cembung } \\
\text { tunggal } \\
\text { dengan warna } \\
\text { putih } \\
\text { kekuningan } \\
\text {-Pewarnaan } \\
\text { gram:positif } \\
\text {-Bentuk:batang }\end{array}$ & \\
\hline 5. & $\mathrm{E}$ & $\begin{array}{l}\text {-Koloni } \\
\text { tunggal, } \\
\text { cembung besar } \\
\text {-Pewarnaan } \\
\text { gram:positif } \\
\text {-Bentuk:batang }\end{array}$ & \\
\hline 6. & $\mathrm{~F}$ & $\begin{array}{l}\text { - Koloni } \\
\text { cembung } \\
\text {-Pewarnaan } \\
\text { gram positif } \\
\text { - Bentuk : } \\
\text { batang yang } \\
\text { berantai }\end{array}$ & \\
\hline
\end{tabular}

Ket : Perbesaran gambar 1000x

\subsection{Identifikasi bakteri asam laktat menggunakan KIT API 50 CHL}

Identifikasi dilakukan untuk melihat kemiripan atau kekerabatan isolat BAL asal dadih dari Sijunjung dengan spesies yang telah teridentifikasi. Penentuan tingkat spesies BAL dilakukan dengan melihat pola fermentasi pada berbagai jenis gula, yaitu menggunakan API KIT 50 CHL. Prinsip pengujian identifikasi menurut panduan Biomerieux Industry yaitu perbandingan profil terhadap database takson pada software. Perbandingan memperhitungkan profil yang diperoleh dengan cara mencari kesamaan typical profile dari setiap takson pada database. Kit API 50 CHL medium digunakan untuk mengidentifikasi genus Lactobacillus dan genus yang berhubungan dengannya melalui fermentasi 49 jenis karbohidrat. Prinsipnya adalah membuat suspensi yang berisi medium dengan mikroorganisme yang diuji, kemudian diinokulasikan ke dalam lubang-lubang yang tersedia pada kit yang masing-masing lubang pada kit berisi satu jenis karbohidrat. Inkubasi dilakukan selama 48 jam pada suhu $36^{\circ} \mathrm{C} \pm 2^{\circ} \mathrm{C}$ dengan pengamatan setiap 24 jam. Selama inkubasi, karbohidrat akan difermentasi menjadi asam ditandai dengan berubahnya warna indikator dari ungu tua menjadi kuning, kecuali lubang nomor 25 yang berisi karbohidrat esculin. Fermentasi esculin positif apabila warna berubah dari ungu tua menjadi hitam. Data reaksi positif dan negatif dari fermentasi karbohidrat ini dirangkum dan identifikasi untuk menentukan strain dilanjutkan dengan menggunakan software APIWEB.

Hasil analisis software APIWEB memberikan tingkatan profil yang berbeda-beda berdasarkan persentase keterkaitan isolat bakteri dan takson dengan melihat \% id (persentase kedekatan identitas) dan indeks $\mathrm{T}$ (kemiripan takson), yaitu 1) "excellent" (\% $\%$ id $>99,9$ dan $\mathrm{T}>0,75), 2)$ "very good" ( $\% \mathrm{id}>99,0$ dan $\mathrm{T}>0,5)$, 3) "good" (\% id $>90,0$ dan T>0,25), dan 4) "acceptable" (\% Id $>80,0$ dan $\mathrm{T}>0), 5)$ "low discrimination" jika dua, tiga atau empat takson dari genera yang berbeda dipilih oleh program, 6) " not reliable" jika jumlah dari\% id kurang dari $80 \%$, 7) "presumptive”, adalah menyarankan bahwa strain dikirim ke pusat rujukan untuk identifikasi tambahan, dan 8) "doubtful" jika takson memiliki beberapa tes terhadap identifikasi hadir di antara mereka taxons dipilih, 9) “unacceptable" jika jumlah profil tidak cukup dekat untuk setiap taksa database. Mungkin diperlukan pelengkap tes off-line memastikan hasil.

Dari enam isolat yang dilanjutkan ke tahap proses identifikasi menggunakan Kit API $50 \mathrm{CHL}$, diperoleh bahwa diperoleh satu isolat yang memberikan hasil identifikasi yang "very good" dengan nilai \% id 93,1\% dan $\mathrm{T}$ 0,64 yaitu Isolat $\mathrm{F}$ yang teridentifikasi sebagai Lactobacillus paracasei ssp paracasei. Sementara untuk isolat yang lain tidak memberikan hasil yang baik, sehingga identifikasinya tidak dapat diterima. Hal ini diduga disebabkan karena isolat belum murni. Hasil pewarnaan gram menunjukkan bahwa isolat termasuk bakteri gram positif dengan bentuk batang yang berantai. Hasil ini sesuai dengan hasil yang ditampilkan (Safitri, 2010) dimana karakteristik morfologi dari Lactobacillus paracasei berbentuk sel batang tipis, ujung bentuk persegi dan posisi berantai dengan rata-rata ukuran sel 0,4-1,0 x 2-4 $\mu \mathrm{m}$ (Safitri, 2010).

Hasil uji fermentasi selama 48 jam dengan menggunakan perangkat kit API $50 \mathrm{CH}$ menunjukkan bahwa isolat yang diuji mampu mendegradasi 25 komponen gula yang ditandai dengan adanya perubahan warna dari ungu tua menjadi kuning sebanyak 24 buah dan 1 (satu) sel mengalami perubahan warna dari ungu tua menjadi hitam, yaitu sel nomor 25, karena pada sel tersebut berisi esculin, dimana reaksi positif terjadi apabila warna berubah menjadi hitam. Hasil fermentasi 
gula-gula menggunakan Kit API 50 CHL dan profil fermentasi karbohidrat dari spesies yang diidentifikasi dapat dilihat pada Gambar 3 dan Tabel 2. Berdasarkan kemampuan mendegradasi gula (reaksi positif) yang dilanjutkan dengan pengujian menggunakan perangkat lunak APIWEB maka disimpulkan bahwa strain BAL yang teridentifikasi adalah Lactobacillus paracasei ssp paracasei 1 (Gambar 4).
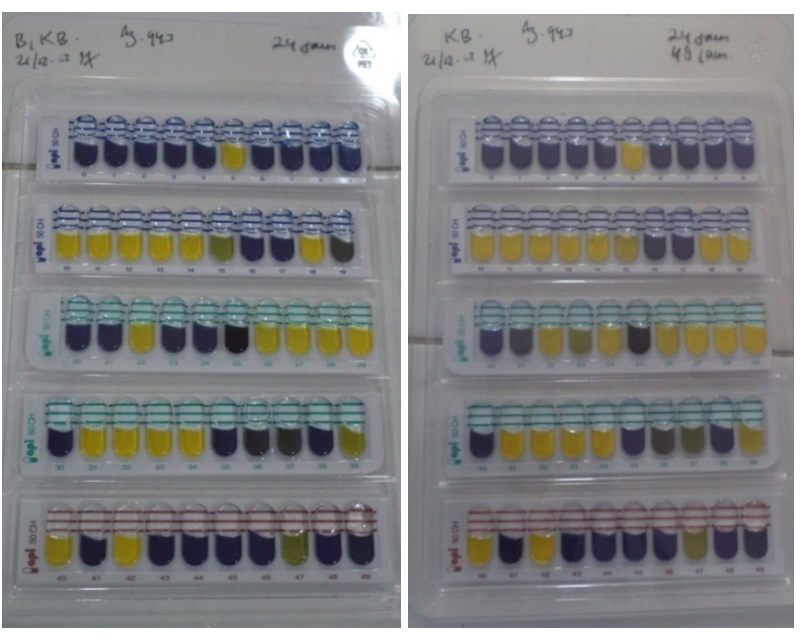

Gambar 3. Hasil uji fermentasi gula-gula bakteri setelah 24 dan 48 jam menggunakan perangkat kit API $50 \mathrm{CHL}$ Ket : Reaksi + : perubahan warna dari ungu tua menjadi kuning, reaksi - : tidak terjadi perubahan warna, kecuali hole nomor 25 , reaksi + jika terjadi perubahan warna dari ungu tua menjadi hitam

Tabel 2.

Profil Fermentasi Karbohidrat dari spesies Lactobacillus paracasei $\mathrm{ssp}$ paracasei 1

\begin{tabular}{|c|c|c|c|c|c|}
\hline No & $\begin{array}{l}\text { Fermentasi } \\
\text { karbohidrat }\end{array}$ & Hasil & No & $\begin{array}{l}\text { Fermentasi } \\
\text { karbohidrat }\end{array}$ & Hasil \\
\hline 0. & Control & Negatif & 25. & Esculin & Positif \\
\hline 1. & Glycerol & Negatif & 26. & Salicin & Positif \\
\hline 2. & Erythritol & Negatif & 27. & Cellobiose & Positif \\
\hline 3. & D-Arabinose & Negatif & 28. & Maltose & Positif \\
\hline 4. & L-Arabinose & Negatif & 29. & Lactose & Positif \\
\hline 5. & Ribose & Positif & 30 . & Melibiose & Negatif \\
\hline 6. & D-Xylose & Negatif & 31. & Saccharose & Positif \\
\hline 7. & L-Xylose & Negatif & 32. & Trehalose & Positif \\
\hline 8. & Adonitol & Negatif & 33. & Inulin & Positif \\
\hline 9. & $\begin{array}{l}\text { B-Metil-D- } \\
\text { xiloside }\end{array}$ & Negatif & $\begin{array}{l}34 . \\
35 .\end{array}$ & $\begin{array}{l}\text { Melezitose } \\
\text { D-Raffinose }\end{array}$ & $\begin{array}{l}\text { Positif } \\
\text { Negatif }\end{array}$ \\
\hline 10. & Galactose & Positif & 36. & Amidon & Negatif \\
\hline 11. & D-Glucose & Positif & 37. & Glycogen & Negatif \\
\hline 12. & D-Fructose & Positif & 38. & Xylitol & Negatif \\
\hline 13. & D-Mannose & Positif & 39. & a-Gentiobiose & Positif \\
\hline 14. & L-Sorbose & Positif & 40. & D-Turanose & Positif \\
\hline 15. & Rhamnose & Positif & 41. & D-Lyxose & Negatif \\
\hline 16. & Dulcitol & Negatif & 42. & D-Tagatose & Positif \\
\hline 17. & Inositol & Negatif & 43. & D-Fucose & Negatif \\
\hline 18. & Mannitol & Positif & 44. & L-Fucose & Negatif \\
\hline 19. & Sorbitol & Positif & 45. & D-Arabitol & Negatif \\
\hline 20. & $\begin{array}{l}\text { A-Methyl-D- } \\
\text { mannose }\end{array}$ & Negatif & $\begin{array}{l}46 . \\
47 .\end{array}$ & $\begin{array}{l}\text { L-Arabitol } \\
\text { Gluconate }\end{array}$ & $\begin{array}{l}\text { Negatif } \\
\text { Positif }\end{array}$ \\
\hline 21. & $\begin{array}{l}\text { A-Methyl-D- } \\
\text { glucoside }\end{array}$ & Negatif & 48. & $\begin{array}{l}\text { 2-Keto- } \\
\text { gluconate }\end{array}$ & Negatif \\
\hline 22. & $\begin{array}{l}\text { N-Acetyl- } \\
\text { glucosamine }\end{array}$ & Positif & 49. & $\begin{array}{l}\text { 5-Keto- } \\
\text { gluconate }\end{array}$ & Negatif \\
\hline 23. & Amygdalin & Positif & & & \\
\hline 24. & Arbutin & Positif & & & \\
\hline
\end{tabular}

Lactobacillus paracasei adalah bakteri gram-positif, tidak membentuk spora, bersifat heterofermentatif fakultatif, anaerob fakultatif, berbentuk batang yang merupakan penghuni umum dari saluran usus manusia. Strain L. Paracasei juga ditemukan secara alami dalam fermentasi sayuran, susu dan daging. Strain spesies ini digunakan dalam banyak produk makanan, termasuk fermentasi tradisional susu dan keju. Strain dari spesies ini juga digunakan dalam makanan probiotik dan suplemen diet (Danisco, 2010).

Bakteri asam laktat ini telah lama dianggap aman dan cocok untuk konsumsi manusia. Sangat sedikit contoh infeksi telah dikaitkan dengan bakteri ini dan beberapa hasil penelitian telah dipublikasi membahas keamanannya. L. paracasei ssp paracasei terdaftar di inventarisasi Mikroorganisme dengan dokumentasi sejarah penggunaannya pada makanan manusia.

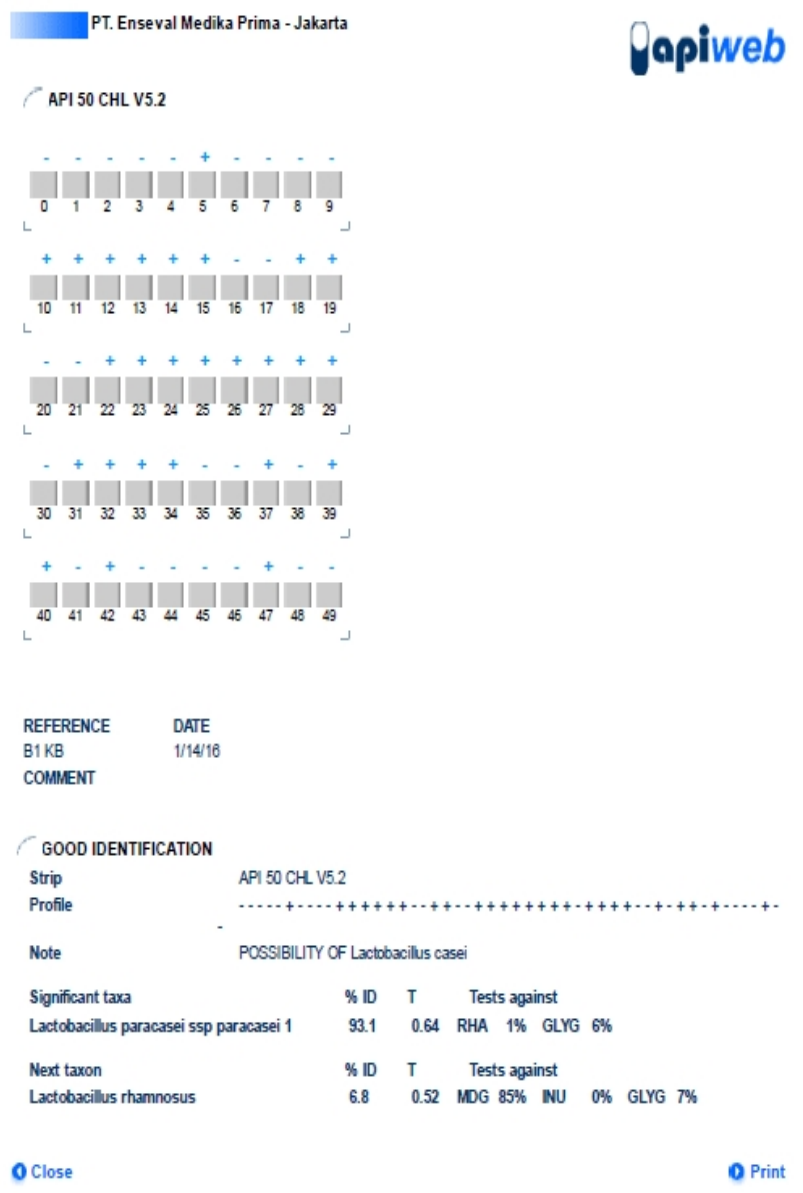

Gambar 4. Hasil pembacaan identifikasi bakteri asam laktat dari dadih Sijunjung menggunakan software APIWEB

\subsection{Karakteristik probiotik Lactobacillus paracasei ssp paracasei}

Menurut definisi probiotik yang berlaku umum, mikroorganisme probiotik harus tetap hidup saat ditelan untuk manfaat kesehatan. Ini berarti bahwa probiotik harus bertahan hidup dalam perjalanannya melalui saluran pencernaan. Berbagai ciri diyakini dapat dijadikan ukuran untuk bertahan pada bagian saluran pencernaan, yang paling penting adalah toleransinya pada kondisi sangat asam yang ada dalam perut dan tahan terhadap konsentrasi garam empedu dalam usus kecil. 
Tabel 3.

Jumlah koloni bakteri Lactobacillus paracasei ssp paracasei yang tumbuh pada kondisi asam dengan $\mathrm{pH}$ 3,5

\begin{tabular}{|c|c|c|}
\hline \multirow{2}{*}{$\begin{array}{l}\text { Lama/waktu } \\
\text { terpapar oleh } \\
\text { asam pH 3,5 (jam) }\end{array}$} & \multicolumn{2}{|c|}{ Rata-rata jumlah koloni yang tumbuh } \\
\hline & koloni/g & Siklus Log \\
\hline 0 & $1,35 \times 10^{6}$ & 6,13 \\
\hline 4 & $1,07 \times 10^{6}$ & 6,03 \\
\hline 7 & $5,28 \times 10^{5}$ & 5,72 \\
\hline 24 & $4,79 \times 10^{5}$ & 5,68 \\
\hline
\end{tabular}

Hasil penelitian menunjukkan bahwa bakteri Lactobacillus paracasei ssp paracasei yang diisolasi dari dadih Sijunjung mampu bertahan dengan baik dalam kondisi asam rendah dengan $\mathrm{pH} 3,5$ sampai jam ke 24 sebagaimana terlihat pada Tabel 3. Hasil ini sejalan dengan studi in vitro yang dilakukan sebelumnya sebagaimana yang ditampilkan pada Tabel 4, yang menunjukkan bahwa L. paracasei Lpc-37 sangat tahan terhadap kondisi $\mathrm{pH}$ rendah dan menunjukkan moderat resistensi terhadap garam empedu pada konsentrasi seperti dalam duodenum. Selain itu mempunyai kemampuan aktivitas antioksidan dan sebagai immunomudulator sehingga lebih lanjut dapat memberikan efek yang menguntungkan bagi kesehatan saluran pencernaan (Danisco, 2010).

Tabel 4.

Karakteristik Lactobacillus paracasei

\begin{tabular}{llc}
\hline Karakteristik & \multicolumn{1}{c}{ Ketahanan } & Keterangan \\
\hline $\begin{array}{l}\text { Toleransi } \\
\text { terhadap asam }\end{array}$ & $\begin{array}{l}80-90 \% \text { survival in } \\
\text { hydrochloric acid } \\
\text { and pepsin }(1 \%) \text { at } \\
\text { pH 3 for } 1 \mathrm{~h} \text { at } 37^{\circ} \mathrm{C}\end{array}$ & ++++ \\
& $\begin{array}{l}(<60 \% \text { survival in } \\
\text { Toleransi }\end{array}$ & + \\
$\begin{array}{l}\text { terhadap garam } \\
\text { empedu }\end{array}$ & containing medium $)$ & \\
\hline
\end{tabular}

Selected characteristics of $L$. paracasei Lpc-37 (internally generated data):++++ Excellent; +++ Very good; ++ Good; + Fair, Sumber : (Danisco, 2010)

\subsection{Sediaan kering bakteri L. paracasei ssp paracasei setelah proses freeze drying}

\subsubsection{Kadar air sediaan kering bakteri $L$. paracasei ssp paracasei}

Sediaan Lactobacillus paracasei ssp paracasei kering seperti yang dihasilkan dari penelitian ini mempunyai kadar air sebesar 8,53\%, sebagaimana yang tampak pada Gambar 6. Kadar air bahan akan mempengaruhi umur simpan bahan. Semakin tinggi kadar air, maka bahan akan semakin tidak tahan untuk disimpan. Dengan kadar air 8,53\% ini diharapkan sediaan kering bakteri dapat tahan dalam penyimpanan. Hasil penelitian (Adyatma, 2015) menyatakan bahwa kadar air mikrokapsul tiga suspensi bakteri probiotik yang dihasilkan setelah proses freeze drying pada hari ke- 0 penyimpanan rata-rata kurang dari 3\%. Rendahnya kadar air dari mikrokapsul yang dihasilkan ini dipengaruhi oleh penggunaan freeze dryer. Metoda freeze drying dapat meninggalkan kadar air produk hingga 1\% (Sumanti et al., 2016).

Hasil penelitian ini juga tidak berbeda jauh dengan penelitian (Seveline, 2005), kadar air enkapsulasi bakteri probiotik dengan penambahan penyalut dekstrin sebesar $7,16 \%$ sd $12,73 \%$, penyalut dekstrin dan triasil gliserol dengan metode spray drying 6,57\% - 8,36\%, sedangkan yang menggunakan teknik freeze drying dengan bahan penyalut skim dan sukrosa kadar airnya jauh lebih tinggi, yaitu sebesar $19,87 \%$ dan $27,12 \%$.

Sementara itu pengeringan menggunakan spray dryer yang dilakukan oleh peneliti sebelumnya menghasilkan kadar air pada mikrokapsul suspensi bakteri $L$. plantarum dengan bentuk kultur suspensi yang menggunakan bahan enkapsulasi campuran susu skim gum arab sebesar 9,2\% dan bahan enkapsulasi susu skim sebesar 8,9\% (Rizqiati et al., 2009). Hasil yang serupa juga disampaikan oleh penelitian lain, bahwa pembuatan susu kedelai fermentasi instan menggunakan bakteri $L$. acidophilus dan sukrosa 5\% sebagai krioprotektan dengan metode freeze drying mempunyai kadar air $9,83 \%$ (Nisa et al., 2008).

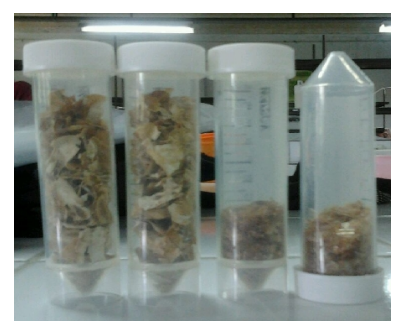

(a)

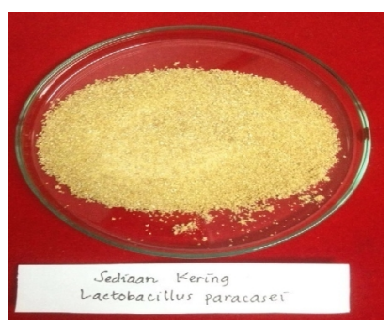

(b)
Gambar 6. (a) Sediaan kering Lactobacillus paracasei ssp paracasei setelah proses freeze drying. (b) Sediaan kering Lactobacillus paracasei ssp paracasei halus

\subsubsection{Viabilitas Lactobacillus paracasei dalam sediaan kering}

Uji ketahanan (viabilitas) bakteri probiotik terenkapsulasi dilakukan dengan membandingkan jumlah total bakteri probiotik sebelum dan setelah proses Freeze drying. Viabilitas bakteri Lactobacillus paracasei ssp paracasei disajikan pada Tabel 5.

Tabel 5.

Perhitungan Viabilitas Sediaan Kering Bakteri $L$. paracasei ssp paracasei

\begin{tabular}{|c|c|c|c|c|}
\hline No & $\begin{array}{l}\text { Keadaan sel } \\
\text { bakteri }\end{array}$ & $\begin{array}{l}\text { Jumlah } \\
\text { Koloni/ml }\end{array}$ & $\begin{array}{l}\text { Log } \\
\text { jumlah sel }\end{array}$ & Viabilitas \\
\hline 1. & $\begin{array}{l}\text { Suspensi sel } \\
\text { + biopoly- } \\
\text { mer }\end{array}$ & $1,76 \times 10^{9}$ & 9,25 & $100 \%$ \\
\hline 2. & $\begin{array}{l}\text { Sel + } \\
\text { biopolymer } \\
\text { kering }\end{array}$ & $1,89 \times 10^{8}$ & 8,28 & $89,52 \%$ \\
\hline
\end{tabular}

Dari Tabel 5 diketahui bahwa proses freeze drying menyebabkan terjadi penurunan jumlah sel bakteri Lactobacillus paracasei dari 1,76 x $10^{10} \mathrm{koloni} / \mathrm{ml}$ menjadi $1,89 \times 10^{9} \mathrm{koloni} / \mathrm{ml}$ atau turun sebesar 0,97 siklus log, dengan viabilitas $89,52 \%$. Hasil ini menunjukkan bahwa Lactobacillus casei mempunyai 
ketahanan yang baik terhadap proses freeze drying. Menurut (Semyonov et al., 2010) hasil penelitian ini masuk dalam kategori high viability dengan viabilitas lebih dari 60\%. (Harmayani et al., 2001) juga melaporkan bahwa terjadi penurunan viabilitas sel pada pembuatan kultur kering dari Lactobacillus sp. Dad 13, L. acidophilus D2 dan L. plantarum Mut 7 dengan freeze drying berkisar 0,5 sampai 2 siklus log.

Penurunan ketahanan sel selama freeze drying kemungkinan disebabkan oleh proses pembekuan dan pengeringan. Proses pembekuan menyebabkan sel kehilangan kestabilannya, sehingga menjadi mudah rusak selama pengeringan. Faktor utama penyebab kerusakan akibat pengeringan sel bakteri kemungkinan karena shock osmotic dengan kerusakan membran dan perpindahan ikatan hydrogen yang berpengaruh terhadap sifat-sifat makromolekul hidrofilik dalam sel (Puspawati et al., 2010).

Walaupun ada penurunan viabilitas bakteri setelah pengeringan beku, populasi sel bakteri kering Lactobacillus paracasei masih memenuhi standar FAO/WHO bahwa jumlah populasi bakteri yang harus ada dalam kultur starter berkisar $10^{6}-10^{7} \mathrm{cfu} / \mathrm{gram}$. Suatu medium pembawa probiotik minimal mengandung mikroba probiotik sebanyak $10^{6}-10^{8} \mathrm{cfu} / \mathrm{ml}$ atau $10^{8}-$ $10^{10} \mathrm{cfu} / \mathrm{gr}$ (preparat kering) (Onayanti et al., 2015). Hal ini berarti suspensi biopolimer yang terdiri dari natrium alginat dan skim mampu memberikan perlindungan terhadap sel, sehingga mengurangi terjadinya kontak langsung dengan lingkungan. Beberapa penelitian enkapsulasi bakteri yang menggunakan kalsium alginat yang ditambah dengan Hi-mize, kalsium alginat dan chitosan serta skim juga dapat meningkatkan ketahanan membran dan melindungi dinding sel bakteri pada saat proses pengeringan (Krasaekoopt et al., 2003; Onayanti et al., 2015; Sultana et al., 2000).

\section{Kesimpulan}

Dari hasil isolasi bakteri asam laktat yang berasal dari dadih Kabupaten Sijunjung, diketahui bahwa isolat merupakan bakteri gram positif, berbentuk sel batang, ujung bentuk persegi dan posisi berantai. Identifikasi menggunakan perangkat kit API 50 CHL menunjukkan bahwa isolat yang diuji mampu mendegradasi 25 komponen gula. Pengujian menggunakan perangkat lunak APIWEB menyatakan bahwa strain BAL yang teridentifikasi adalah Lactobacillus paracasei ssp paracasei 1. Bakteri berpotensi sebagai kandidat probiotik karena kemampuannya bertahan pada kondisi asam pH 3,5 selama 24 jam.

Penggunaan biopolimer natrium alginat : skim (1:1) dengan konsentrasi 5\%, mampu memberikan perlindungan terhadap sel, sehingga mengurangi terjadinya kontak langsung dengan lingkungan. Pengeringan dengan metode freeze drying menyebabkan terjadi penurunan jumlah sel bakteri Lactobacillus paracasei dari $1,76 \times 10^{10} \mathrm{koloni} / \mathrm{ml}$ atau 9,25 siklus log menjadi $1,89 \times 10^{9} \mathrm{koloni} / \mathrm{ml}$ atau 8,28 siklus $\log$, turun sebesar 0,97 siklus log, dengan viabilitas $89,52 \%$. Namun masih termasuk dalam kategori viabilitas yang baik.

\section{Ucapan terima kasih}

Ucapan terima kasih disampaikan kepada Sdr. Dian Pramana Putra yang telah membantu pelaksanaan penelitian ini.

\section{Deklarasi kontribusi penulis}

Yulia Helmi Diza berperan sebagai kontributor utama dalam artikel ini, sedangkan Alfi Asben dan Tuty Anggraini sebagai kontributor anggota.

\section{Daftar pustaka}

Adrianto, A., 2011. Enkapsulasi Lactobacillus casei dengan teknik ekstrusi sebagai starter untuk pembuatan dadih susu sapi.

Adyatma, K.H.., 2015. Pendugaan umur simpan mikroenkapsulasi suspensi bakteri probiotik dengan model arrhenius.

Annan, N.T., Borza, A.D., Hansen, L.T., 2008. Encapsulation in alginate-coated gelatin microspheres improves survival of the probiotic Bifidobacterium adolescentis $15703 \mathrm{~T}$ during exposure to simulated gastro-intestinal conditions. Food Res. Int. 41, 184-193. https://doi.org/10.1016/j.foodres.2007.11.001

Asben, A., Anggraini, T., Diza, Y.H., 2014. The effect of coating matrix and drying method on encapsulation process of Lactobacillus casei against its dried preparation viability.

BPS, P.S., 2018. Provinsi Sumatera Barat dalam angka. Padang.

Cardenas, A., Arguelles-Monal, W., Goycoolea, F.M., Higuera-Ciapara, I., Peniche, C., 2003. Diffusion through membranes of the polyelectrolyte complex of chitosan and alginate. Macrromol Biosci 3, 535539. https://doi.org/10.1002/mabi.200300031

Chávarri, M., Marañón, I., Ares, R., Ibáñez, F.C., Marzo, F., Villarán, C., 2010. Microencapsulation of a probiotic and prebiotic in alginate-chitosan capsules improves survival in simulated gastro-intestinal conditions. Int. J. Food Microbiol. 142, 185-189. https://doi.org/10.1016/j.ijfoodmicro.2010.06.022

Danisco, 2010. Lactobacillus paracasei LPC-37 ®.

Elida, M., 2002. Profil bakteri asam laktat dari dadih yang difermentasi dalam berbagai jenis bambu dan potensinya sebagai probiotik. Institut Pertanian Bogor.

Handayani, G.N., Ida, N., R, A.R., 2014. Pemanfaatan susu skim sebagai bahan dasar dalam pembuatan produk olahan makanan tradisional danke dengan bantuan bakteri asam laktat. J. Farm. FIK UINAM 2, $56-61$.

Hardiningsih, R., Nonta, R., Napitupulu, R., Yulinery, T., 2006. Isolasi dan uji resistensi beberapa isolat lactobacillus pada $\mathrm{pH}$ rendah. B I O D I V E R S I T A S 7, 15-17. https://doi.org/10.13057/biodiv/ d070105

Harmayani, E., Ngatirah, Rahayu, E.S., Utami, T., 2001. Ketahanan dan viabilitas probiotik bakteri asam laktat selama proses pembuatan kultur kering dengan metode freeze dan spray drying. J. Teknol. dan Ind. 
Pangan XII, 126-132.

Homayouni, A., Azizi, A., Ehsani, M.R., Yarmand, M.S., Razavi, S.H., 2008. Effect of microencapsulation and resistant starch on the probiotic survival and sensory properties of synbiotic ice cream 111, 50-55. https://doi.org/10.1016/ j.foodchem.2008.03.036

Husni, A., Subaryono, Pranoto, Y., Tazwir, Ustadi, 2012. Pengembangan metode ekstraksi alginat dari rumput laut Sargassum sp. sebagai bahan pengemntal. Agritech 32, 1-8.

Kim, S., Yong, S., Hun, S., Song, O., Shin, I., Su, D., Jin, H., 2008. Effect of microencapsulation on viability and other characteristics in Lactobacillus acidophilus ATCC 43121. Leb. Technol. 41, 493500. https://doi.org/10.1016/j.lwt.2007.03.025

Krasaekoopt, W., Bhandari, B., Deeth, H., 2003. Evaluation of encapsulation techniques of probiotics for yoghurt. Int. Dairy J. 13, 3-13. https://doi.org/10.1016/S0958-6946(02)00155-3

Kusumo, P.D., 2010. Potensi probiotik dalam mekanisme sistem imunitas.

Li, X.Y., Chen, X.G., Sun, Z.W., Park, H.J., Cha, D., 2011. Preparation of alginate / chitosan / carboxymethyl chitosan complex microcapsules and application in Lactobacillus casei ATCC 393. Carbohydr. Polym. 83, 1479-1485. https://doi.org/10.1016/j.carbpol.2010.09.053

Lian, W., Hsiao, H., Chou, C., 2003. Viability of microencapsulated bifidobacteria in simulated gastric juice and bile solution. Int. J. Food Microbilogy 86, 293-301. 1605(02)00563-9

Nedovic, V., Kalusevic, A., Manojlovic, V., Levic, S., Bugarski, B., 2011. An overview of encapsulation technologies for food applications. Procedia Food Sci. 1, 1806-1815. https://doi.org/10.1016/j.profoo. 2011.09.266

Nisa, F.C., Kusnadi, J., Chrisnasari, R., 2008. Viabilitas dan deteksi subletal bakteri probiotik pada susu kedelai fermentasi instan metode pengeringan beku (kajian jenis isolat dan konsentrasi sukrosa sebagai krioprotektan). J. Teknol. Pertan. 9, 40-51.

Onayanti, N., Budji, R.G., Sartini, 2015. Uji viabilitas probiotik asal saluran pencernaan itik pedaging Anas domesticus yang dienkapsulasi dengan metode cross link.

Ozyurt, V.H., Otles, S., 2014. Properties of probiotics and encapsulated probiotics in food. Acta Sci. Pol., Technol. Aliment. 13, 413-424.

Picot, A., Lacroix, C., 2004. Encapsulation of Bifidobacteria in whey protein-based microcapsules and survival in simulated gastrointestinal conditions and in yoghurt. Int. Dairy J. 14, 505-515. https://doi.org/10.1016/j.idairyj.2003.10.008

Prado, C., Parada, J.L., Pandey, A., Soccol, C.R., 2008. Trends in non-dairy probiotic beverages. Food Res. Int. 41, 111-123. https://doi.org/10.1016/j.foodres. 2007.10.010

Pratama, D.R., Aritonang, S.N., Adnani, I., Roza, E., Yellita, Y., Pratama, Y.E., Purwati, E., 2019. Implementasi teknologi yoghurt dengan menggunakan kultur bakteri isolat dari dadiah asal
Nagari Tanjung Bonai untuk pemberdayaan peternak di Jorong Kayu Maranting 2, 481-489.

Puspawati, N.N., Nuraida, L., Adawiyah, D.R., 2010. Penggunaan berbagai jenis bahan pelindung untuk mempertahankan viabilitas bakteri asam laktat yang diisolasi dari air susu ibu pda proses pengeringan beku. J. Teknol. dan Ind. Pangan XXI, 59-65.

Rizqiati, H., Jenie, B.S.., Nurhidayat, N., Nurwitri, C.., 2009. Microcapsul caracteristics of probiotic Lactobacillus plantarum encapsulated by skim. J. Indones. Trop. Anim. Agric 34, 139-144.

Rokka, S., Rantamäki, P., 2010. Protecting probiotic bacteria by microencapsulation: challenges for industrial applications. Eur. Food Res. Technol. 231, 1-12. https://doi.org/10.1007/s00217-010-1246-2

Safitri, R., 2010. Probiotik, basis ilmiah, aplikasi dan aspek praktis (isolasi dan karakterisasi morfologi koloni dan sel Lactobacillus dan Bifidobacterium). Widya Padjajaran.

Sandoval-castilla, O., Lobato-calleros, C., Garcíagalindo, H.S., Alvarez-ramírez, J., Vernon-carter, E.J., 2010. Textural properties of alginate - pectin beads and survivability of entrapped $L b$. casei in simulated gastrointestinal conditions and in yoghurt. Food Res. Int. 43, 111-117. https://doi.org/10.1016/j.foodres.2009.09.010

Sarmento, B., Ribeiro, A., Veiga, F., Sampaio, P., Neufeld, R., Ferreira, D., 2007. Alginate / Chitosan Nanoparticles are Effective for Oral Insulin Delivery. Pharm. Res. 24, 2198-2206. https://doi.org/10.1007/ s11095-007-9367-4

Semyonov, D., Ramon, O., Kaplun, Z., Levin-brener, L., Gurevich, N., Shimoni, E., 2010. Microencapsulation of Lactobacillus paracasei by spray freeze drying. Food Res. Int. 43, 193-202. https://doi.org/ 10.1016/j.foodres.2009.09.028

Seveline, 2005. Pengembangan produk probiotik dari isolat klinis bakteri asam laktat dengan menggunakan teknik pengeringan semprot dan pengeringan beku. Istitut Pertanian Bogor.

Shi, L.E., Li, Z.H., Zhang, Z.L., Zhang, T.T., Yu, W.M., Zhou, M.L., Tang, Z.X., 2013. Encapsulation of Lactobacillus bulgaricus in carrageenan-locust bean gum coated milk microspheres with double layer structure. LWT - Food Sci. Technol. 54, 147-151. https://doi.org/10.1016/j.lwt.2013.05.027

Smith, J., Charter, E., 2010. Functional food product development, 1st ed. Blackwell Publishing Ltd.

Sultana, K., Godward, G., Reynolds, N., Arumugaswamy, R., Peiris, P., Kailasapathy, K., 2000. Encapsulation of probiotic bacteria with alginate - starch and evaluation of survival in simulated gastrointestinal conditions and in yoghurt. Int. J. Food Microbilogy 62, 47-55.

Sumanti, D.M., Lanti, I., Hanindah, I.-I., Sukarminah, E., Giovanni, A., 2016. Pengaruh konsentrasi susu skim dan maltodekstrin sebagai penyalut terhadap viabilitas dan karakteristik mikroenkapsulasi suspensi bakteri Lactobacillus plantarum menggunakan metode freeze drying. J. Penelit. Pangan 1, 7-13. https://doi.org/10.24198/ jp2.2016.vol1.1.02

Sunaryanto, R., Marwoto, B., 2013. Isolasi, identifikasi 
dan karakterisasi bakteri asam laktat dari dadih susu kerbau. J. Sains dan Teknol. Indones. 14, 228-233.

Surono, I.S., 2016. Ethnic fermented foods and baverage of Indonesia, in: Jyoti Prakash Tamang (Ed.), Ethnic Fermented and Alcoholic Beverage of Asia. Springer India., pp. 341-382. https://doi.org/10.1007/978-81322-2800-4

Surono, I.S., Nishigaki, T., Endaryanto, A., Waspodo, P., 2008. Indonesia biodiversitiesfrom microbes to herbal plants as potential functonal food. J. Fac. Agric. 44, 23-27.

Trabelsi, I., Bejar, W., Ayadi, D., Chouayekh, H., Kammoun, R., Bejar, S., Salah, R. Ben, 2013. Encapsulation in alginate and alginate coatedchitosan improved the survival of newly probiotic in oxgall and gastric juice. Int. J. Biol. Macromol. 1-7. https://doi.org/10.1016/j.ijbiomac.2013.06.035

Triana, E., Yulianto, E., Nurhidayat, N., 2006. Uji viabilitas Lactobacillu sp. Mar 8 terenkapsulasi. Biodiversitas 7, 114-117. https://doi.org/10.13057/ biodiv/d070204

WHO, FAO, 2006. Probiotics in food, health and nutritional properties and guidelines for evaluation. Rome.

Widodo, Soeparno, Wahyuni, E., 2003. Bioencapsulation of probiotics (Lactobacillus casei) with pollard and wheat flour and its roles for the acidification rate and Viability. J. Teknol. dan Ind. Pangan XIV, 98-106.

Wirawati, C.U., Sudarwanto, M., Lukman, D., Wientarsih, I., 2017. Karakteristik dan pengembangan dadih dari susu sapi sebagai alternatif dadih susu kerbau. Wartazoa 27, 95-103. https://doi.org/10.14334/wartazoa.v2712.1595

Zubaidah, E., Saparianti, E., Hindrawan, J., 2012. Studi aktivitas antioksidan pada bekatul dan susu skim terfermentasi probiotik (Lactobacillus plantarum B2 dan Lactobacillus acidophillus ). J. Teknol. dan Ind. Pangan 13, 111-118. 